\title{
Stygioides italica Mazzei et Yakovlev - new species of Cossidae (Lepidoptera) from Italy
}

\section{Stygioides italica Mazzei et Yakovlev - новый вид Cossidae (Lepidoptera) из Италии}

\author{
P. Mazzei ${ }^{1}$, R.V. Yakovlev ${ }^{2,3}$ \\ П. Маццеи ${ }^{1}$, Р.В. Яковлев ${ }^{2,3}$
}

\footnotetext{
${ }^{1}$ DYNASTES srl., Via di Torre Morena 46/I-48, 00118 Roma, Italy; mazzeip@tin.it

${ }^{2}$ Altai State University, Lenina 61, 656049 Barnaul, Russia.

${ }^{2}$ Алтайский государственный университет, пр. Ленина 61, Барнаул 656049, Россия. E-mail: yakovlev_asu@mail.ru

${ }^{3}$ Tomsk State University, Laboratory of Biodiversity and Ecology, Lenina pr. 36, 634050 Tomsk, Russia.

${ }^{3}$ Томский государственный университет, лаборатория биоразнообразия и экологии, пр. Ленина 36, Томск 634050. Россия.
}

KEY WORDS: Cossidae, Stygioides italica, fauna, Italy.

КЛЮЧЕВЫЕ СЛОВА: Cossidae, Stygioides italica, фауна, Италия

ABSTRACT. The description of the new species of Cossidae Stygioides italica sp.n. from Central Italy is presented.

РЕЗЮМЕ. Представлено описание нового вида Stygioides italica sp.n. из Центральной Италии.

\section{Introduction}

The genus Stygioides Bruand, 1853 (Cossidae) was designated for Stygia colchica Herrich-Schäffer, 1851 [Bruand, 1853]. Currently the genus consists of six species: S. colchicus (Herrich-Schäffer, 1851) = S. tricolor Lederer, 1858, S. ivinskisi Saldaitis et Yakovlev, 2007, S. nupponenorum Yakovlev et Saldaitis, 2011, S. aethiops (Staudinger, 1887), S. aethiops (Staudinger, 1887), S. persephone (Reisser, 1962), S. psyche (Grum-Grshimailo, 1893). Congeners are widely spread in Mediterranea, Western Asia and in the west of Central Asia [Yakovlev, 2011, 2015; Yakovlev, Dubatolov, 2013].

All species of the genus are rarely met in collections, as they are not attracted to a light and can hardly be seen at daytime. Imagines can be found from vegetation with the use of sweep netting. Recently described species S. ivinskisi Saldaitis et Yakovlev, 2007 and S. nupponenorum Yakovlev et Saldaitis, 2011 were attracted to pheromone traps [Saldaitis et al, 2007; Yakovlev, 2011].

Members of the genus Stygioides have been recorded for Italy for several times. Curò [1890] reported $S$. colchica from Puglia (Brindisi), Ragusa [1893] reported three specimens of S. colchica? from Sicily (two of them from Madonie range: la Carbonara). Turati [1919] determined S. tricolor for "Villa Pamphili, parco urbano all'interno di Roma". Dannehl [1927] reported it for "campagna romana", Bertaccini et al. [1997] men- tioned it for "Romagna e Calabria", Parenzan and Porcelli [2006] reported it for Lazio and Puglia. These publications taking into account $S$. colchica was designated for the fauna of Italy [Yakovlev, 2011].

\section{Materials and methods}

On July 1, 2001 the first author of the given work took a picture of and collected a male specimen from flowers Gymnadenia conopsea (L.) R. Br., 1813 (Orchidaceae) in outskirts of Campo Felice (Abruzzi, Italy) (Figs 1-3). Grassi et al. [2007] figured it male. In studying the specimen, it turned out to be the member of the newly established species. Its description is given below. The genitalia slide was examined with the use of Zeiss Stemi $2000 \mathrm{C}$ microscope and the image was taken with the Olympus XC 50 camera.

\section{Stygoides italica sp.n.}

Figs 3-5.

MATERIAL. Holotype: ${ }^{7}$, Campo Felice, AQ [Abruzzi Prov., Central Italy], 1.06.2002 (Museum Witt, Munich, Germany).

DESCRIPTION. Forewing length $7 \mathrm{~mm}$. Head, thorax and abdomen densely covered with black and grey hairs. Antennae bipectinate; rami short, 1.5 the length of flagellum diameter. Forewing rather acute apically, elongate. Wing transparent, covered with sparse grey and brownish scales; costal margin bears a well-defined suffusion, extending into grey brown area apically; dark suffusion well-defined near to the base of the forewing; slender dark border along the margin of the wing; fringe long, grey. Hindwing short, semitransparent, with a well-defined greyish brown suffusion along the anal margin and a less defined one on the wing area; wing margin with a slender dark border; fringe long, grey.

Male genitalia are of typical for the generic members ground plan. Uncus broad, of medium length, rounded apically. Tegumen medium-sized. Arms of gnathos long, slender, fused to form a slender membranous gnathos. Valvae 

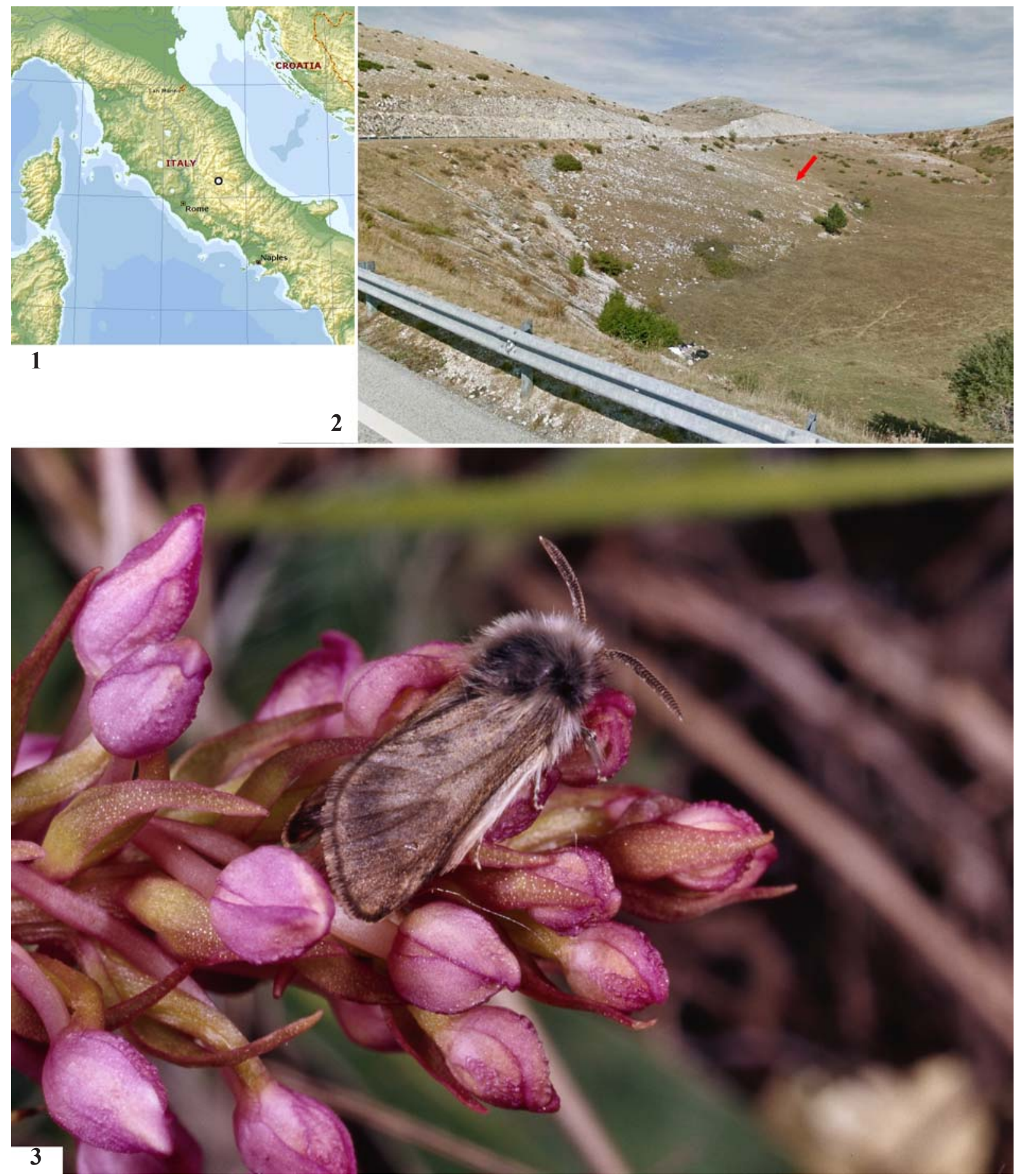

Figs 1-3. Stygioides italica Mazzei et Yakovlev, sp.n.: 1 - type locality of on the map; 2 - biotope; 3 - male on the flowers of Gymnadenia conopsea (photo by P. Mazzei).

Рис. 1-3. Stygioides italica Mazzei et Yakovlev, sp.n.: 1 - типовая местность на карте; 2 - биотоп; 3 - самец на цветах Gymnadenia conopsea (фото by П. Маццеи).

long, lanceolate, narrowing towards apex, apical thirds membranous; transition area of sclerotization between sclerotized and membranous parts uneven, distinct, slender; valva bears a massive crest on the costal margin. Arms of transtilla short, apically obtuse and semicircle, basally thick. Juxta complex, saddle-shaped, with short ventrally directed processes; lateral process long dorsally directed, slightly divergent. Saccus semicircle, large. Aedeagus slightly longer than valva, strongly curved in the middle third, gradually narrowing distally. Vesica opening dorso-apical, 1/2 as long as aedeagus; vesica without cornuti.

Female unknown.

DIAGNOSIS. The new species is closely related to S. colchicus (Herrich-Schäffer, 1851) (terra typica - Ama- 


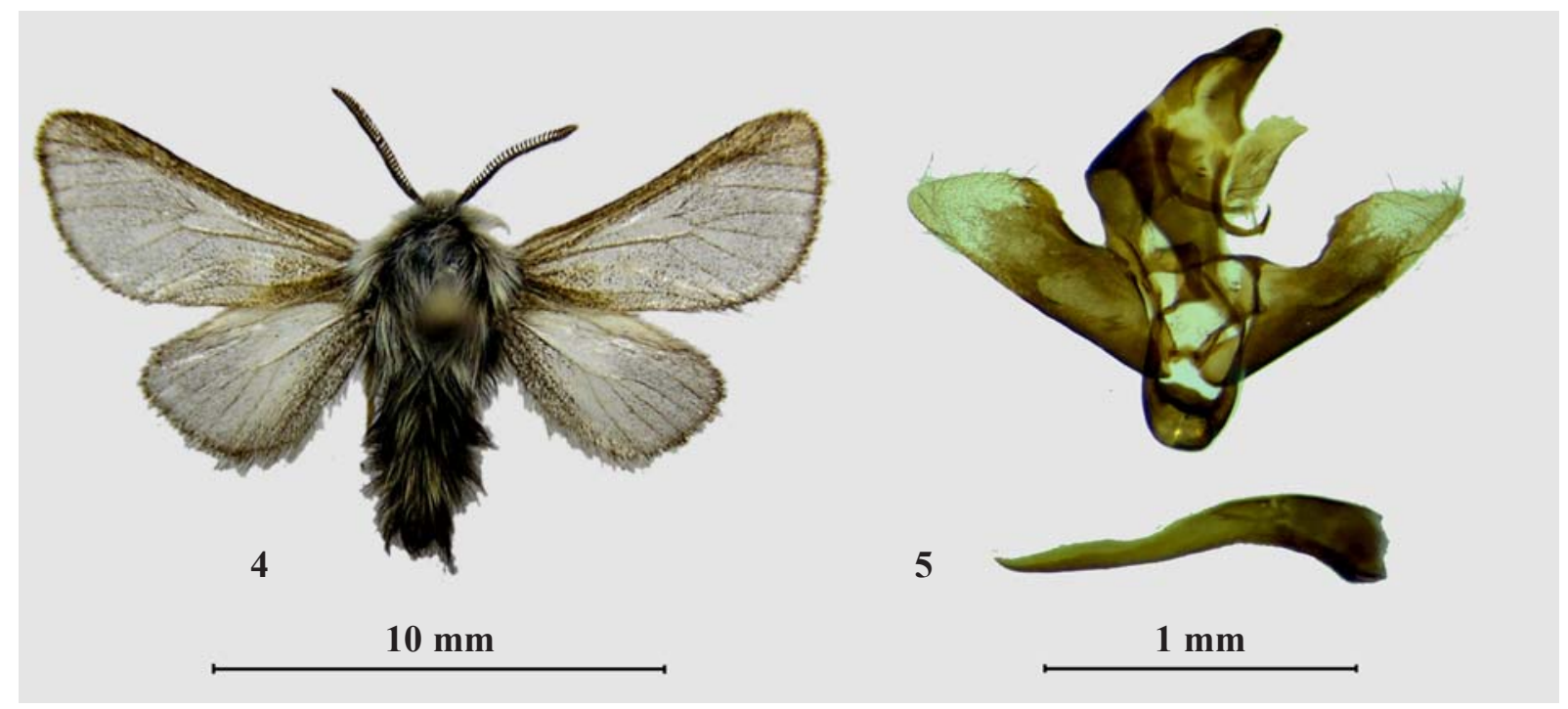

Figs 4-5. Stygioides italica Mazzei et Yakovlev, sp.n., Holotype: 4 - general view; 5 - genitalia.

Рис. 4-5. Stygioides italica Mazzei et Yakovlev, sp.n., голотип: 4 - внешний вид; 5 - гениталии.

sia [Turkey]), and well distinguished from it with a number of characters: rami considerably shorter in male; a well defined blackening along the costal margin of the forewing; much shorter apical third of valva; a slenderer, more curved aedeagus, with a longer opening of vesica.

ACKNOWLEDGEMENT. The authors thank Prof. M. Silantjeva (Barnaul) for the given opportunity to use the Zeiss Stemi 2000 C microscope and the Olympus XC 50 camera.

\section{References}

Bertaccini E., Fiumi G., Provera P. 1997. Cossidae // Bombici e Sfingi d'Italia (Lepidoptera, Heterocera). Vol.2. Monterenzio (BO). P.147-157.

Bruand M. 1852. Monographie des Psychides // Mémoires de la Société d'Emulation du Doubs. T.(2)3. P.17-127.

Curò A. 1890. Aggiunte alla parte prima del Saggio di un Catalogo dei Lepidotteri d'Italia // Bullettino della Società entomologica italiana. T.21 Nos 3-4. (1889). P.76-85.

Dannehl F. 1927. Sammelreise nach Mittelitalien 1926 und ihre Ergebnisse // Lepidopterologische Rundschau. Bd.1. Hf.1. S.11-12.
Grassi A., Pimpinelli I., Pinzari M., Zilli A. 2007. Some noteworthy records of macromoths from Central Italy (Lepidoptera) // Bollettino dell'Associazione Romana di Entomologia. Vol.62. Nos14. P.131-144.

Parenzan P., Porcelli F. 2006. I macrolepidotteri italiani // Phytophaga. T.15. P.1-1051 [CD-Rom, allegato in .pdf].

Ragusa E. 1893. Note lepidotterologiche // Il Naturalista siciliano. T.12. No.9. P.206-207.

Saldaitis A., Yakovlev R.V., Ivinskis P. 2007. Carpenter Moths (Insecta: Lepidoptera, Cossidae) of Lebanon // Acta Zoologica Lithuanica. Vol.17. No.3. P.191-197.

Turati E. 1919. A mille metri sull' Apennino Modenese. Note di Lepidotterologia e descrizione di tre nuove specie di Micri // Atti della Societa italiana di scienze naturali. Vol.58. P.147-187.

Yakovlev R.V. 2011. Catalogue of the Family Cossidae of the Old World (Lepidoptera) // Neue Entomologische Nachrichten. Bd.66. P.1-130.

Yakovlev R.V. 2015. Patterns of Geographical Distribution of Carpenter Moths (Lepidoptera: Cossidae) in the Old World // Contemporary Problems of Ecology. Vol.8. No.1. P.36-50. http://dx.doi.org/10.1134/S1995425515010151.

Yakovlev R.V., Dubatolov V.V. 2013. Distribution of CarpenterMoths (Lepidoptera, Cossidae) in the Palaearctic Deserts // Entomological Review. Vol.93. No.8. P.991-1004. http:// dx.doi.org/10.1134/S0013873813080071. 